DOI: $10.20472 / E S .2020 .9 .1 .011$

\title{
GENERATION Y ON LABOUR MARKET - PERCEPTION OF WORK VALUES AND QUALITY OF JOB
}

\section{AGNIESZKA STANIMIR}

\begin{abstract}
:
The purposes of the study were: to characterize the Generation $Y$ as participants in the labour market; to recognize economic conditions of labour markets; to describe social and individual factors of job values/conditions that concern Generation Y. The article presents the results of the carried out research and its main conclusions. Following hypothesis were constructed: the countries that met the conditions for joining the European Union at the same time differ in their respective ways of developing the labour market and differ on these issues from the countries which joined the Union in other periods. Some hypotheses regarding the perception of the workplace were also tested. For this purpose, subjective variables were determined for the assessment of working and private life conditions. The Eurostat data (due to the homogeneity of variables on the labour market) as well as the data from the European Social Survey (due to the representativeness of the data and the subjective nature of respondents' assessments) were used to conduct the study. As to the analysis techniques, ordering methods were selected: Hellwig's and TOPSIS and also twostep cluster analysis. The indicated set of data and selected analysis methods fully enabled the characterization of the phenomenon. In addition, it was possible to compare the results obtained from both ordering methods. As a result, it was found that a higher level of GDP per Capita does not always affect rising the employment rate and lowering the Generation's $Y$ unemployment rate. The methods of ordering made it possible to indicate the countries that in the period from 2005 to 2017 obtained the best characteristics of the labour market. The twostep cluster for Generation $Y$ indicated that it is not important to divide this age cohort into older and younger group because their assessments of quality and working conditions didn't differ. The analysis carried out over three years showed how the attitudes of the inhabitants of the selected countries towards the balance between private life and work, working conditions and the possibilities of influencing organizational issues at work have changed.

The obtained results cannot be compared, in direct way, with the findings of other researches. There are no studies in which analogous methods would be used for a similar population, time range and age cohort.
\end{abstract}

\section{Keywords:}

Generation Y, labour market, working conditions, quality of work, TOPSIS, Hellwig's ordering, two-step cluster

JEL Classification: J00, C38, A14

\section{Authors:}

AGNIESZKA STANIMIR, Wroclaw University of Economics and Business, Poland, Email: agnieszka.stanimir@ue.wroc.pl 


\section{Citation:}

AGNIESZKA STANIMIR (2020). Generation Y on labour market - perception of work values and quality of job. International Journal of Economic Sciences, Vol. IX(1), pp. 202-223., 10.20472/ES.2020.9.1.011 


\section{Introduction}

The main objective of the study was to identify work values and attributes describing quality of job, which are relevant from the point of view of Generation Y. The supplementary goal was to identify labour market conditions which apply to Generation Y. Taking into account the literature characteristics of Generation $\mathrm{Y}$, the aim of the study was also to recognize social and individual factors of job values/conditions that concern Generation Y. Analysis of work values and the quality of job is one of the key aspects of the development of the labour market. Hansen and Leuty (2012) state that work values are strictly related to these aspects of a job that are necessary to obtain job satisfaction. That is why this analysis cannot be carried out without the participation of employees and their opinions, because their expectations and requirements towards employers inspire to create jobs that are friendly to employees, so that work will not only be an obligation but also a source of satisfaction and a way to self-fulfilment. This is in accordance with the Declaration of Philadelphia concerning the aims and purposes of the International Labour Organization.The declaration was passed in 1944 and in 1946 it was incorporated into the ILO constitution as an annex. In this Declaration an obligation is recognized "to further among the nations of the world programmes which will achieve (ILO, 1944):

a) full employment and the raising of standards of living;

b) the employment of workers in the occupations in which they can have the satisfaction of giving the fullest measure of their skill and attainments and make their greatest contribution to the common well-being."

Generation Y, whose perception of job is the subject of the study, behaves on the labour market in a very different way compared to the other generations. However, this is not the only difference between generations. Disparities between people belonging to different age cohorts are noticeable in the area of social behaviour, perception of the family and family life, consumption patterns, the way of spending free time and many others.

In literature, it is difficult to find references to research of a similar scope. Parry and Urwin (2011) analysed generations from different age cohorts and their perception of work values. Smola and Sutton (2002) have extensively described various studies conducted in a direction similar to those presented in the article. Tolbize (2008), in turn, analysed the differences in behaviour in the workplace of different generations. The most thematic similar research is the study of Kim, Knight and Crutsinger (2009) conducted on the impact of work environment on satisfaction and commitment at work. However, the study was conducted among students. Wylandet al. (2016) presented the results of research on job satisfaction, job preference, work values, but without dividing the population into generations. Stanimir conducted similar thematic research but covers other periods and using different methods. In the work (Stanimir, 2014) the participation of various generational groups in the labour market was analysed. In the works (Stanimir 2015a, 2015b) the attitudes and skills presented by Generation $Y$ on the labour market were examined.

The research results presented in the article were obtained based on representative samples, which were determined due to the Eurostat and European Social Survey databases. This action seems the most accurate due to the purpose of the study, which is to compare the behaviour of the Generation $Y$ as part of the perception of working conditions and quality of work in the European Union and especially countries that joined the European Union together with Poland. Analysing the 
behaviours of the Generation $Y$ on the national soil in regional terms, it seems reasonable to conduct primary researches divided into professional groups or business activities. Such analyses will be undertaken by the author in the future.

Taking into account the characteristic features of the Generation $Y$ and the changing contributions of generations on the labour markets, the following research hypotheses were formed:

- in the European Union countries, despite striving for economic cohesion, there are differences in main indices levels on the labour market;

- the situation on the labour market in Poland and another countries that joined the EU in 2004 improved;

- the quality of work assessment carried out by Generation $Y$ changes over time;

- gender and age are factors that differentiate the quality of work assessment in selected age cohort;

- Generations $\mathrm{Y}$, in countries that have joined the European Union together with Poland, differ in terms of importance of factors characterizing the quality of work;

- the important factors for the Generation $Y$ are work-life balance, no necessity to influence the organizational and political decisions of the company, the ability to decide on a daily work.

\section{Literature review on Generation $\mathrm{Y}$ and work values}

Generation $Y$ is one of the four generations encountered on the labour market: Traditionalists (1922-1945) - some of them are still active, Baby Boomers (1946-1964), Generation X (19651979), Generation Y (1980-2000).

Figure 1: Activity rates (AR) and Employment rates (ER) by age cohorts in 2017

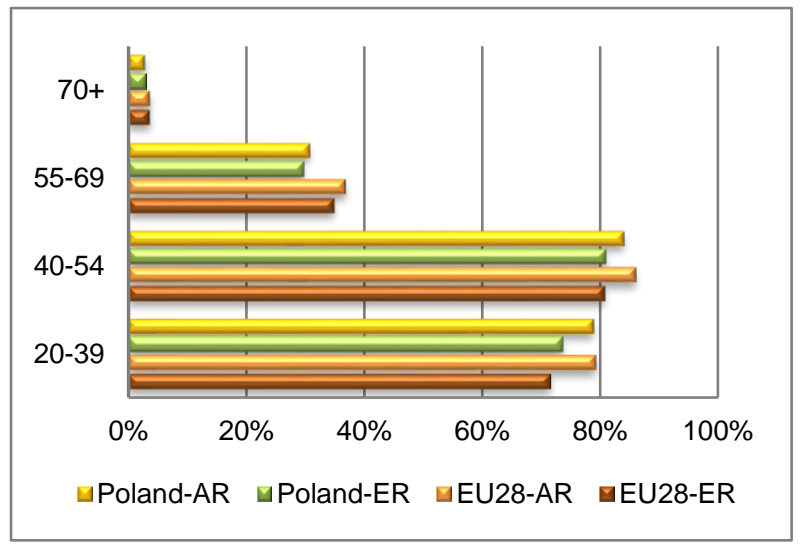

Source: Own elaboration on ground Eurostat data [lfsa_argan, Ifsa_ergan].
Figure 2: Population on 1 January 2018 as \% of total population by age

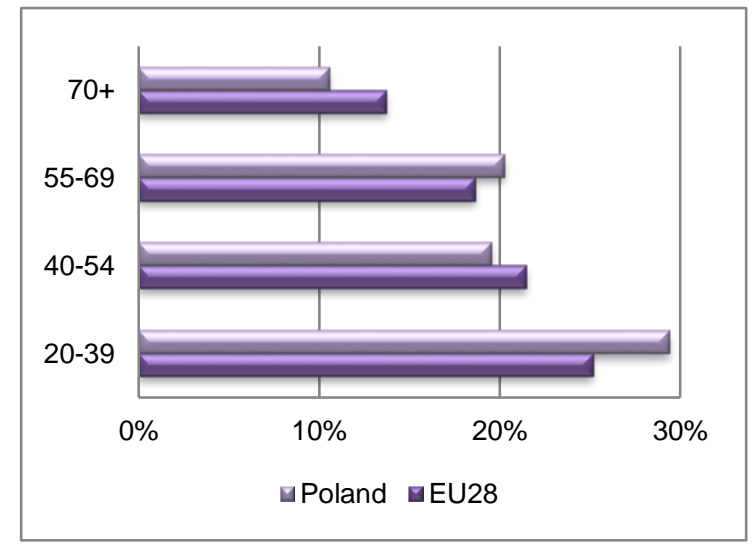

Source: Own elaboration on ground Eurostat data [demo_pjangroup].

In Figure 1, the employment and activity rate of people belonging to particular generational groups can be observed. The source of the data is Eurostat data basis. The data is published in a five-year range. For this reason, it was not possible to match the age ranges accurately with the age of people counted among one of four generations. As Kołodziejczyk (2018) showed in his study, the determination of the unemployment and employment rate depends on the factors taken into 
account for the construction of the indicator. Therefore, when comparing the results obtained for Poland and the European Union, the data should be taken from the same source.

Among traditionalists (Fig. 1), professionally active and employed people constitute $4 \%$ of the European Union's population as well as $3 \%$ in Poland. In 2017, the highest employment rate was observed for Generation X, both in Poland and the European Union. Among the people from the Baby Boomers generation there are the smallest differences between the employment rate and the activity rate. The employment rate of the Generation $\mathrm{Y}$ in 2017 was $72 \%$ in Poland and $74 \%$ in the European Union. Assuming that Generation $Y$ was born in the years 1980-2000, it should be remembered that the Figure 1 does not cover the entire Generation Y. The youngest participants of this generation, although they can be counted among active people, often do not work but continue their education. Stanimir (2014) wrote about the analysis of employment and unemployment rates for Generation Y, compared to older generations.

At the beginning of 2018 , Generation $Y$ constituted almost $30 \%$ of the population in Poland, $25 \%$ in the European Union (see Fig. 2). It is the most numerous group in Poland and the European Union, and it should be noted that people aged 18-19 who are also part of the Generation $\mathrm{Y}$ are not included in population fractions shown in Figure 2.

The assumption that Generation $Y$ was born in the 80 s and 90 s of the twentieth century causes this group to be diverse internally. Therefore, this group includes people who are already participants of the labour market (age 25-38), those that are starting a job search and the youngest Yers who are completing their training or study (aged 18-24). It seems important to distinguish between older and younger Yers. Schroer (2015) did likewise in relation to Baby Boomers, distinguishing Boomers I-Traditionals and Boomers II-Generation Jones. The factors, which significantly contributed to the intensification of the differences between and within generations were the development and expansion of new technologies after 1990 as well as political changes in Europe at the turn of the 1980s and 1990s. The latter factors influenced the assessment of the socio-economic situation by the older generations and the reaction to stimuli from the family environment presented by the Generation Y. Khera and Malik (2014, pp. 66) pointed that people from Generation $Y$ "have been brought in the time when economies of the world were moving toward globalization" and they "grew up in the digital age" as wrote Gentry et al. (2011, pp. 41).

For Generation $Y$ different birth years are considered in different countries - examples can be found in Favero, Heath (2012), Hole, Zhang, Schwartz (2010), Lester et al. (2012), Lichy (2012), Stanimir (2015a, 2015b), Treuren, Anderson (2010). Stanimir (2015a), Barwińska-Małajowicz (2011), Martini (2005) give many terms for describing the Generation Y, which correspond to the characteristics of this group of people. Generation $Y$ is called the millennium generation, jobhoppers, e-generation, net-generation Wannabees, next generation, Generation Me, I-pop generation, e-generation, fussy generation. Very often, according to literature, Generation $Y$ is the first generation with unlimited and free access to the computers during their schooling. This phenomenon cannot be perceived in the same way in all countries in the world. This statement is true for high developed countries. In other countries IT-classes were implemented in the late nineties. As Lyons, Duxbury and Higgins (2007) suggest Generation Y have a technological savvy. Smith, Roebuck and Elhaddaoui (2016, pp. 57) indicated that Generation $Y$ is "sociable, goaloriented, self-confident, social minded, and accepting of diversity". Tolbize (2008) writes about Generation Y as about Millenials, Nexters, Generation www, the Digital Generation. 
Lester et al. (2012, pp. 342) writes that "each generational cohort possesses a unique set of characteristics and preferences that distinguish their work place tendencies". Differences between generations are receding over time because of changes in the socio-economic situation of the household to which belongs a member of the chosen generation and changes in the near and distant surroundings. But the generational differences sharpen again at the end of life. Taking into account the purpose of the research, very important is Bąkowska's statement (2013, pp. 10). She writes that "each generation has its own occupational preferences and its own market needs,, and this is the reason why the analysis of perception of, for example, job quality, should be made for every generation group separately. Deal (2007) suggests that the same values are important for all generations but they express them in different way. Parment (2013) indicates that in job seeking process very important are identity, image and social networks. Generation's $Y$ expectation of constant feedback from superiors results in a lack of ability to make critical decisions and in the need to indicate by superiors how to proceed (Gursoy, Maier, Chi, 2008). The feedback concept is often misunderstood by the Generation Y.

Smith, Roebuck and Elhaddaoui (2016) suggest that for Generation Y organizational politics or group decision-making processes is not important as much as for other generations. They want to gain new skills to complete tasks faster, because they are also known as multitasking people. In the Parment study (2013, pp. 6) it is indicated that $36.4 \%$ of respondents said that "feedback is very important for them and affects their efficiency". The description of the behaviour of the Generation $\mathrm{Y}$ in the labour market is complemented by the fact that they are the youngest generation on labour market, but they realize that their knowledge and skills are very high, so they want to be equally, respectfully treated. However, it should be remembered that every next generation entering the labour market after graduation, is better educated in theoretical issues than older generations. It is therefore important for all generations to benefit from theoretical and practical skills of others. The functioning of Generation $Y$ can be described as speed action and the expectation of equally rapid effects followed by a quick disappointment or even frustration in the lack of results or achievement of bad results. Other appreciated values of work are pointed by Hansen and Leuty (2012): these are importance of freedom at work and social values, interacting with others, as well as prestige work values. However, it is worth noting that Generation $Y$ is very socially and culturally open and thanks to the ability to use the lack of territorial limitations in communications, they work without problems in multicultural teams.

The features listed above describing Generation $Y$ show to a certain extent what is their perception of the work values and the quality of employment. As in Szwedzik (2015) work and professional activity allow people to change the world and improve their economic, professional, social and state status. Such a role of work is valid for all generations, but they differ when it comes to attachment to the workplace, loyalty and requirements regarding the relevance of their education to their profession. For the Generation Y, the change of job is an immediate decision, i.e. if not this job than other. The issue of employment, regardless of the employee's generation, is associated with age management in enterprises. Rogozińska-Pawełczyk (2014, pp. 20) indicates that "the purpose of age management is to stimulate and maintain activity in the private and professional sphere, not only in terms of income but also social contacts, psychophysical condition, participation in the acquisition of new technologies" (own translation). On the basis of this definition, it can be concluded that age management is, from the perspective of Generation Y, a fully adjusted set of actions aiming at using the advantages of the Generation $Y$ and at eliminatingthe occurrence of 
negative traits. Therefore, age-related activities help in achieving higher loyalty, involvement in enterprises' activities, return to identification of employees with the company and decrease of jobhoopping, while improving and encouraging the exchange of skills and knowledge between generations. The areas of age management are, among others, flexible working time, protection and promotion of health and the way of designing workplaces. These areas perfectly fit into the Generation $Y$ job perception. For them flexible working time supports the maintenance of work-life balance and the employer should offer various types of benefits, whether health or social. Proper age management will enable the employer to accomplish another workplace attribute important for Generation Y, i.e. recognition and use of their skills and to propose participation in various issues related to the organization and policy of the company. Crespo, Simoes and Pinto (2017) indicated that from an individual's point of view the quality of job stems from the socio-economic characteristics of employees and the attributes of the company. The authors have shown in their study that there are no significant differences in job quality due to age of employees (Crespo, Simoes and Pinto, 2017). There is another economic problem associated with the Generation Y: life expectancy. Proposed by Kasnauskiene and Michnevic (2017) the life expectancy model shows that the 20-29 age group is highly important as far as this issue is concerned, because the horizon length for future undertakings plays a crucial role now, such as expectations of longer retirement. Advances in health and social care extend life expectancy on the economy, without increase in retirement age or real lifetime earnings.

\section{Data and methods of analysis}

In conducted analysis, the data from Eurostat and European Social Study (ESS) was used. This choice was made because of the representativeness of the data. For ESS data, weights were applied as Design weights multiplied by Population size weights. Due to the data available in Eurostat, where the age is divided into five-year periods, in the analysis respondents aged 20-34 appear. This action is accurate because of the heterogeneity of the Generation Y.

This age range corresponds to adults who belonged in 2017 to the Generation $\mathrm{Y}$. The data available in public statistics (Eurostat) is published for a 5-year cohorts. The selection of a group of 20-34year-olds is sufficient, because the share of working people aged 18-19 is low, and there are many indications in the literature to include those born after 1995 to the Generation Z. Behaviours of people between 35-38 years are interwoven with the characteristics of Generation X. A comparison of 20-34-year-olds from 2017 with people belonging to the same age cohort but in 2005-2016 allows indicating whether there have been observed radical changes in the perception of the quality of work by young people.

In the study were used linear ordering methods and the twostep cluster analysis.

\section{Hellwig's ordering and TOPSIS}

Linear ordering methods allow ranking objects due to the set of characteristics of the research problem. Balicki points out that in linear ordering, the measurement of diversity should characterize how much, on average, one object is better (or worse) than another object due to variable values (Balicki, 2013). 
In the analysis are used two methods: Hellwig's ordering and TOPSIS. In both methods, it is necessary to ensure the comparability of variables. To this end, the following formula of normalization is used:

$$
z_{i j}=\frac{\left(x_{i j}-\bar{x}_{j}\right)}{S_{j}}
$$

where: $z_{i j}$ - normalized value of $j$-th variable in $i$-th object; $x_{i j}$ - observed value of $j$-th variable in $i$ th object; $\bar{x}_{j}$ - mean of $j$-th variable; $S_{j}$ - standard deviation of $j$-th variable.

Standardization method, by which a variable is rescaled, finally lead to mean value of each variable equal to zero and a standard deviations equal to 1. In Hellwig's ordering (Hellwig, 1968) and in the TOPSIS method (Hwang, Yoon, 1981) the next step ${ }^{1}$ is identical.

Determine ideal $\left(z_{+j}\right)$ and for TOPSIS also non-ideal solution $\left(z_{-j}\right)$

$$
\begin{aligned}
& z_{+j}=\left\{\begin{array}{l}
\max _{i}\left\{z_{i j}\right\} \text { associated with benefit criteria } \\
\min _{i}\left\{z_{i j}\right\} \text { associated with cost criteria }
\end{array}\right. \\
& z_{-j}=\left\{\begin{array}{l}
\min _{i}\left\{z_{i j}\right\} \text { associated with benefit criteria } \\
\max _{i}\left\{z_{i j}\right\} \text { associated with cost criteria }
\end{array}\right.
\end{aligned}
$$

In both methods, calculation of the Euclidean distance of each object from the ideal solution is needed:

$$
d_{i+}=\sqrt{\sum_{j=1}^{m}\left(z_{i j}-z_{+j}\right)^{2}}, i=1,2, \ldots, n
$$

The smaller this distance is, the more the object is similar to the pattern (ideal solution) and the higher the level of the research problem for this object is.

In Hellwig's ordering synthetic measure is defined as follow:

$$
s_{i}=1-\frac{d_{i+}}{d_{0}}, i=1,2, \ldots, n
$$

where: $d_{0}=\bar{d}_{0}+2 S_{d_{0}}$ and $\bar{d}_{0}=\frac{1}{n} \sum_{i=1}^{n} d_{i+}, S_{d_{0}}=\sqrt{\frac{1}{n} \sum_{i=1}^{n}\left(d_{i+}-\bar{d}_{0}\right)^{2}}$.

The distance determined in this way refers to the maximum possible distance, which is $d_{0}$ between the ideal solution and non-ideal solution.

In TOPSIS, integrated evaluation index (the relative closeness to ideal solution) is counted as follow:

$$
c_{i}=\frac{d_{i-}}{d_{i+}+d_{i-}}, i=1,2, \ldots, n
$$

where: $d_{i-}=\sqrt{\sum_{j=1}^{m}\left(z_{i j}-z_{-j}\right)^{2}}, i=1,2, \ldots, n$.

Both measures, $s_{i}$ and $c_{i}$, usually take values in the range $<0,1>$. Higher values of these indicators indicate better-rated objects.

\footnotetext{
${ }^{1}$ In the description of both methods, the nomenclature of the TOPSIS method was used, as a more widely known one.
} 
It is clear that $c_{i}=1$ when the normalized observations of the $i$-th object are consistent with $z_{+j}$, and $c_{i}=0$ when the normalized observations of the $i$-th object are consistent with $z_{-j}$.

The measure $s_{i}$ in the Hellwig's method, can take a negative value for an object for which the values of variables significantly more differ from the ideal solution than other objects, and when the number of objects is large.

In the Hellwig's method, the ordering synthetic measure results from the relation between the distance of object to ideal solution and the interval of variability of all the distances between objects and the ideal solution. Whereas, in the TOPSIS method, the relative proximity to the ideal solution is indicated by the relation of the object's distance to the non-ideal solution to the range given by the distance to the ideal and non-ideal solution. For objects with average observations, neither similar to ideal solutions nor to non-ideal, $d_{i+}$ and $d_{i-}$ have similar values (the value of the integrated evaluation index will oscillate around 0.5 ). The TOPSIS method prefers objects significantly different from the others and which affecting the range of the distance of objects to ideal and nonideal solutions.

Based on the differences in the level of the synthetic variables, the classes of objects may be determined due to the $s_{i}$ values (and for $c_{i}$ respectively):

$$
\begin{gathered}
1: s_{i} \geq \bar{s}+S_{s_{i}} \\
2: \bar{s}+S_{s_{i}}>s_{i} \geq \bar{s} \\
3: \bar{s}>s_{i} \geq \bar{s}-S_{s_{i}} \\
\quad 4: s_{i}<\bar{s}-S_{s_{i}}
\end{gathered}
$$

where: $\bar{s}=\frac{1}{n} \sum_{i=1}^{n} s_{i}, S_{s_{i}}=\sqrt{\frac{1}{n}\left(s_{i}-\bar{s}\right)^{2}}$

In the first class are objects with the best results of the $s_{i}$ or $c_{i}$, in the fourth class - with the worst results.

Thanks to this simple method of objects classification, the obtained division guarantees the greatest possible diversity of objects values from different classes and the smallest possible diversity of objects in the same classes (Nowak, 1980).

Based on Hellwig's $\left(s_{i}\right)$ and TOPSIS $\left(c_{i}\right)$ synthetic measures, global taxonomic measures of development $\left(G T M D_{i}\right)$ is calculated according to the following procedure (Panek, 2014):

- determining the development pattern with optimal values of group indicators:

$$
z_{0 h}=\max _{i} s_{h, i},(i=1,2, \ldots, n, h=1,2, \ldots, k)
$$

- calculation of the distances between each object and the pattern:

$$
g_{0 i}=\sqrt{\sum_{j=1}^{m}\left(z_{0 h}-s_{h, i}\right)^{2}},(i=1,2, \ldots, n)
$$

- calculation of the global taxonomic measure of development:

$$
G T M D_{i}=1-\frac{g_{0 i}}{g_{0}},(i=1,2, \ldots, n)
$$

where: $g_{0}=\bar{g}_{0 i}+3 S_{g_{0 i}}$ and $\bar{g}_{0}=\frac{1}{n} \sum_{i=1}^{n} g_{0 i}, S_{g_{0 i}}=\sqrt{\frac{1}{n} \sum_{i=1}^{n}\left(g_{0 i}-\bar{g}_{0}\right)^{2}}$.

The lower the $G T M D_{i}$ values are, the worse the assessment of the object in groups and in the overall approach of the study is. 


\section{Twostep cluster analysis}

Another method that was used is the twostep cluster analysis. This method allows the occurrence of non-metric and metric variables in the dataset. Another advantage of this method is the large sample size. It is recommended more than 200 observations (Trpkova, Tevdovski, 2010, pp.304). These two aspects significantly distinguish the twostep cluster analysis from the widely used clustering algorithm, like k-means clustering or agglomerative hierarchical techniques.

If there are only metric (or quasi contiguous) variables in the dataset then Euclidean distance is used during the analysis. However, if at least one of the variables is categorical, then assuming a normal distribution of continuous variables and a multidimensional normal distribution for categorical variables, the log-likelihood distance is used. Trpkova and Tevdovski (2010, pp.304) pointed out, that good results are also obtained even if the distribution assumptions are not met. The analysis is carried out in two steps: pre-clustering of cases and clustering of cases.

In a pre-clustering step, the clustering of observation into small subclusters is conducted. Subclusters in next step are defined as new observations. At this stage, a new data matrix is computed with smaller number of cases for the analysis in next step. Objects are allocated to classes according to the distance criterion. In pre-clustering step, the random order of observations is recommended to exclude the dependency of the results on objects input ordering.

In clustering step, grouping of objects is conducted with traditional clustering methods taking into account data, which contain results calculated in the pre-clustering step. In both steps, the suitable distance measure is needed. The way of calculating the log-likelihood distance is as follows:

$$
\begin{gathered}
d_{i, j}=\xi_{i}+\xi_{j}+\xi_{\langle i, j\rangle} \\
\xi_{v}=-N \cdot\left(\left(\sum_{k=1}^{K^{A}} \frac{1}{2} \cdot \log \left(\hat{\sigma}_{k}^{2}+\hat{\sigma}_{v k}^{2}\right)\right)+\sum_{k=1}^{K^{B}} E_{v k}\right)
\end{gathered}
$$

where $v=\{i, j,\langle i, j\rangle\} ; E_{v \cdot k}=-\sum_{l=1}^{L_{k}}\left(\frac{N_{v k l}}{N_{v}} \cdot \log \frac{N_{v k l}}{N_{v}}\right) ; d_{i, j}$ - the distance between $i$-th and $j$-th cluster, $\langle i, j\rangle$ - number of cluster which is forming by joining of clusters $i$-th and $j$-th; $K^{A}\left(K^{B}\right)$ - the total number of continuous (categorical) variables; $L_{k}$ - the number of categries for the $k$-th categorical variable; $N$ - the number of observations; $N_{v}$ - the number of objects in $v$-th cluster; $N_{v k l}-$ the number of objects in $v$-th cluster, where $k$-th categorical variable takes $l$-th catagory; $N_{k l}-$ the number of objects in $k$-th categorical variable that takes $l$-th category; $\hat{\sigma}_{k}^{2}$ - the estimated variance of the $k$-th continuous variable for the entire dataset; $\hat{\sigma}_{v k}^{2}$ - the estimated variance of the $k$-th continuous variable in $v$-th (Trpkova, Tevdovski, 2010; Şchiopu, 2010).

In the equation (12), the expression $-N\left(\sum_{k=1}^{K^{A}} \frac{1}{2} \cdot \log \left(\hat{\sigma}_{k}^{2}+\hat{\sigma}_{v k}^{2}\right)\right)$ measures the dispersion of the continuous variables $k$ with cluster $v$. The entropy $E_{v \cdot k}$ is a measure of dispersion for categorical variables. If only non-metric variables occur in the study, the $d_{i, j}$ is a measure of entropy.

In next step, as in agglomerative hierarchical clustering, objects are connected into clusters according to the smallest distance.

If the distances are measured using the Euclidean distance, then the object is classified as a part of this class which the centre of gravity is in the nearest distance. Similarly, distances between 
classes are counted as distances between the centres of gravity of classes. Centres of gravity are vectors of mean values of variables in the class.

To determine the number of groups one of Bayes $\left(B I C_{R}\right)$ or Akaike $\left(A I C_{R}\right)$ information criterion should be used. For $R$ clusters:

$$
\begin{gathered}
A I C_{R}=-2 \sum_{r=1}^{R} \xi_{r}+2 m_{R} \\
B I C_{R}=-2 \sum_{r=1}^{R} \xi_{r}+m_{R} \log N
\end{gathered}
$$

where: $m_{R}=R\left\{2 K^{A}+\sum_{k=1}^{K_{B}}\left(L_{k}-1\right)\right\}$ - the number of independent parameters.

$\mathrm{BIC}$ and AIC measures give preliminary information, which solution of $\mathrm{R}$ should be chosen to classify objects. In addition to determining the number of classes, it can be indicated the relative contribution of both types of variables (metric and non-metric) in the creation of classes. In $H_{0}$ (the null hypothesis) the variables can be considered significant. The importance of continuous variables is measured as follows:

$$
t=\frac{\widehat{\mu}_{k}-\widehat{\mu}_{v k}}{\widehat{\sigma}_{v k}} \sqrt{N_{k}}
$$

where $\hat{\mu}_{k}\left(\hat{\mu}_{v k}\right)$ - the estimator of $k$-th continuous variable mean in entire dataset (in chosen cluster). Statistics $t$ has Student distribution with $d f=N_{k-1}$ (the significance level is two-tailed).

For the categorical variable $\chi^{2}$ test is used:

$$
\chi^{2}=\sum_{l=1}^{L_{k}}\left(\frac{N_{v k l}}{N_{k l}}-1\right)^{2} .
$$

Statistics (16) has $\chi^{2}$ distribution with $d f=L_{k}$.

The objects are assigned to the nearest cluster, it means their distance to the centre of gravity of group is smaller than critical value $\mathrm{V}$ (for log-likelihood measure) or $\mathrm{C}$ (for Euclidean distance):

$$
\begin{gathered}
V=\prod_{k} R_{k} \prod_{m} L_{m} \\
C=2 \sqrt{\frac{\sum_{k=1}^{K^{A}} \sigma_{k l}^{2}}{K^{A}}}
\end{gathered}
$$

Otherwise, observations are treated as outlier.

\section{$4 \quad$ Situation on the labour market}

Perception of work and working conditions largely depends on the general attitude of the community to the surroundings prevailing on the labour market. For this reason, it is necessary to look at changes in the labour market taking into account the basic indicators describing this situation.

Using bubble charts the comparison of changes in GDP per capita and employment rate of people aged 20-64 in years 2005 and 2017 are shown (Fig. 3, Fig. 4).

In both figures (Fig.3, Fig.4) employment rates in two age groups are presented. The age cohort spanning 20-34 years is adequate for Generation $Y$ in 2017. In addition, the same age cohort was taken into account in year 2005, because it was intended to compare if the employment rate of young people in their first years on the labour market got better since 2005 to 2017. 
Figure 3: GDP per capita and employment rate of people aged 20-64 and 20-34 in year 2005

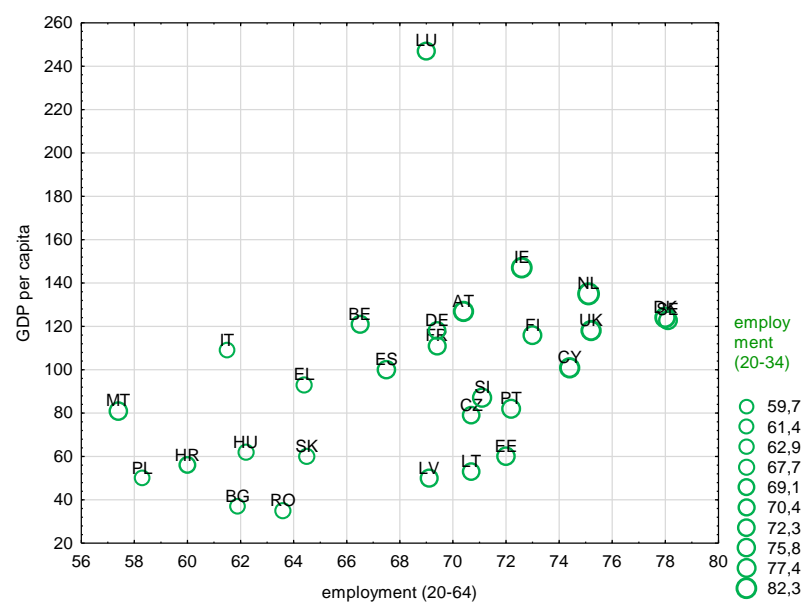

Source: Own elaboration on the EUROSTAT data (prc_ppp_ind, Ifsa_ergan).
Figure 4: GDP per capita and employment rate of people aged 20-64 and 20-34 in year 2017

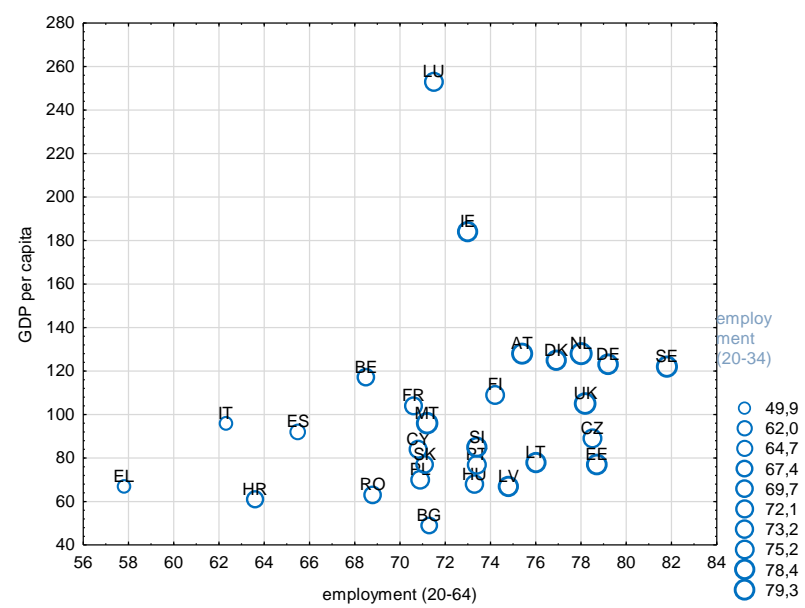

Source: Own elaboration on the EUROSTAT data (prc_ppp_ind, Ifsa_ergan).

In Poland in 2005, the level of GDP per capita was one of the lowest in Europe, and the employment rate of $20-64$ year olds was only $58 \%$. In 2005 , only $59.7 \%$ of $20-34$ year olds Pole were employed, but employment rate for this age cohort in 2017 is higher - and reached $70 \%$. The education of Poles is getting better and more people receive higher education every year. In Poland, according to the guidelines of the Europe 2020 strategy, $45 \%$ of population aged $30-34$ should constitute people with higher education. This goal was achieved in 2017, and from 2010 the number of people aged 30-34 with higher education is upper than the EU average (this difference is constantly growing in favour of Poland). Further, there are more and more jobs in Poland. Job vacancy rate in 2016 was $0.66 \%$ (2015 - 0.54\%, $2012-0.34 \%, 2011-0.42 \%, 2010-0.54 \%)$.

The economic situation shown in Figure 3 and Figure 4 was no equal in chosen countries. Therefore, it was interesting to find countries where the labour market conditions were better than in others, over the years. On the grounds of the following data describing labour market in years 2005-2017 (GDP per capita in PPS, employment rate in age cohorts 20-64, 20-24, 24-29, 30-34, unemployment rate in age cohorts 20-64, 20-29, 30-34, rate of young people in age 20-34 neither in employment nor in education and training) the Hellwig's ordering and TOPSIS method were carried out. The results are presented in Tables 1 and 2.

The results of the TOPSIS and Hellwig's methods are only slightly different. The Hellwig's method gives the opportunity to indicate at what stage the country is, aiming for ideal solution (Eq. 2). The TOPSIS method makes it possible to place the country in the space created by the ideal and nonideal solution. In order to illustrate differences in the results of both methods, the assessments obtained by Germany and Malta were analysed. After applying the TOPSIS method Malta was rated better in 2005 (rank 18) than Germany (place 20). Whereas, after applying the Hellwig's method, these countries have changed positions in order. Since both methods take into account the distance of the object from the ideal solution, the differences obtained in this matter do not affect the differences in ordering (Malta is less similar to the ideal solution than Germany). Therefore, attention should be paid to the remaining elements of order measures in both methods. In the Hellwig's method, the factor influencing the position in the order is the level of the distance from the ideal solution for which, according to the normal distribution, $5 \%$ of the observations have the worst 
results $\left(d_{0}=\bar{d}_{0}+2 S_{d_{0}}\right.$ in equation (5)). Malta always had results closer to worse distances from ideal solution than Germany. This implies Germany's better position in order. On the other hand, in the TOPSIS method, differences in the distances between Malta and Germany from the ideal solution were not as significantly different as in the case of distances from the non-ideal solution, where Germany always had a lower distance. The closer distance from the ideal solution had most influence on Germany's position in order than in the case of Malta.

In both Tables (1 and 2) numbers means rank of country in respective year. The colours describe the class to which the country was classified in a given year, according to the (Eq. 7).

\section{Table 1: Results of TOPSIS method}

\begin{tabular}{|c|c|c|c|c|c|c|c|c|c|c|c|c|c|c|}
\hline & 2005 & 2006 & 2007 & 2008 & 2009 & 2010 & 2011 & 2012 & 2013 & 2014 & 2015 & 2016 & 2017 & GTMD \\
\hline $\mathrm{NL}$ & 1 & 1 & 1 & 1 & 1 & 1 & 1 & 2 & 2 & 2 & 2 & 2 & 1 & 1 \\
\hline DK & 2 & 2 & 2 & 2 & 3 & 4 & 6 & 6 & 6 & 6 & 7 & 7 & 9 & 2 \\
\hline LU & 3 & 3 & 4 & 8 & 2 & 2 & 2 & 1 & 1 & 1 & 1 & 1 & 2 & 3 \\
\hline $\mathrm{IE}$ & 4 & 4 & 5 & 11 & 20 & 18 & 20 & 20 & 17 & 15 & 10 & 9 & 7 & 14 \\
\hline UK & 5 & 6 & 9 & 9 & 8 & 8 & 8 & 8 & 7 & 7 & 6 & 6 & 6 & 6 \\
\hline AT & 6 & 7 & 7 & 4 & 4 & 3 & 3 & 3 & 3 & 3 & 4 & 5 & 5 & 4 \\
\hline CY & 7 & 5 & 3 & 3 & 5 & 6 & 9 & 14 & 20 & 22 & 23 & 23 & 24 & 9 \\
\hline SE & 8 & 8 & 6 & 5 & 6 & 5 & 4 & 5 & 5 & 5 & 3 & 3 & 3 & 5 \\
\hline SI & 9 & 9 & 8 & 6 & 7 & 10 & 12 & 12 & 15 & 18 & 15 & 17 & 13 & 8 \\
\hline $\mathrm{FI}$ & 10 & 11 & 11 & 7 & 9 & 9 & 7 & 7 & 8 & 9 & 13 & 13 & 16 & 7 \\
\hline PT & 11 & 13 & 18 & 17 & 15 & 15 & 16 & 21 & 22 & 21 & 20 & 20 & 18 & 17 \\
\hline $\mathrm{EE}$ & 12 & 10 & 10 & 10 & 23 & 23 & 18 & 15 & 12 & 10 & 9 & 12 & 11 & 16 \\
\hline FR & 13 & 19 & 19 & 15 & 13 & 13 & 13 & 11 & 11 & 14 & 19 & 19 & 21 & 15 \\
\hline $\mathrm{BE}$ & 14 & 16 & 17 & 16 & 12 & 12 & 11 & 10 & 10 & 13 & 16 & 18 & 19 & 13 \\
\hline LT & 15 & 12 & 12 & 14 & 25 & 26 & 22 & 18 & 14 & 12 & 11 & 11 & 12 & 18 \\
\hline ES & 16 & 15 & 15 & 24 & 28 & 28 & 27 & 27 & 27 & 27 & 27 & 27 & 26 & 27 \\
\hline $\mathrm{CZ}$ & 17 & 18 & 14 & 12 & 14 & 14 & 14 & 13 & 13 & 11 & 12 & 10 & 10 & 12 \\
\hline MT & 18 & 17 & 16 & 13 & 11 & 11 & 10 & 9 & 9 & 8 & 8 & 8 & 8 & 11 \\
\hline LV & 19 & 14 & 13 & 18 & 27 & 27 & 23 & 19 & 16 & 16 & 14 & 16 & 17 & 20 \\
\hline $\mathrm{DE}$ & 20 & 20 & 20 & 19 & 10 & 7 & 5 & 4 & 4 & 4 & 5 & 4 & 4 & 10 \\
\hline $\mathrm{HU}$ & 21 & 22 & 25 & 28 & 26 & 22 & 21 & 22 & 21 & 19 & 18 & 14 & 14 & 22 \\
\hline RO & 22 & 21 & 22 & 22 & 19 & 16 & 17 & 17 & 19 & 20 & 21 & 22 & 20 & 19 \\
\hline IT & 23 & 23 & 24 & 27 & 22 & 21 & 19 & 25 & 25 & 26 & 26 & 26 & 27 & 26 \\
\hline EL & 24 & 24 & 27 & 26 & 21 & 25 & 28 & 28 & 28 & 28 & 28 & 28 & 28 & 28 \\
\hline$B G$ & 25 & 25 & 21 & 20 & 17 & 20 & 24 & 24 & 24 & 23 & 24 & 24 & 22 & 23 \\
\hline HR & 26 & 27 & 23 & 23 & 18 & 19 & 26 & 26 & 26 & 25 & 25 & 25 & 25 & 25 \\
\hline SK & 27 & 26 & 28 & 25 & 24 & 24 & 25 & 23 & 23 & 24 & 22 & 21 & 23 & 24 \\
\hline $\mathrm{PL}$ & 28 & 28 & 26 & 21 & 16 & 17 & 15 & 16 & 18 & 17 & 17 & 15 & 15 & 21 \\
\hline
\end{tabular}

Source: Own elaboration on ground EUROSTAT data (prc_ppp_ind, Ifsa_ergan, Ifsa_urgan, edat_Ifse_20).

The situation on labour market in 2005 in Poland was the worst of all analysed countries (Tables 1 and 2), but in next two years the situation started to get better, and finally in 2017 the TOPSIS integrated evaluation index and Hellwig's ordering synthetic measure for Poland were on the middle level. In 2007 when Bulgaria and Romania joined EU, the indices in Hellwig's and TOPSIS methods for those countries were better than for Poland, but in 2017 a better situation was observed in Poland. In 2007, the highest values of the integrated evaluation indices were in Netherland, Denmark, Cyprus, Luxembourg, Ireland and Sweden. In the next years the integrated evaluation indices in Luxemburg and Netherland were still very high, but in Ireland it was seen that since 2008 the situation on labour market was worse from year to year, and since 2009 to 2012 even worse than in Poland. 
Table 2: Results of Hellwig's ordering

\begin{tabular}{|c|c|c|c|c|c|c|c|c|c|c|c|c|c|c|}
\hline & 2005 & 2006 & 2007 & 2008 & 2009 & 2010 & 2011 & 2012 & 2013 & 2014 & 2015 & 2016 & 2017 & GTMD \\
\hline $\mathrm{NL}$ & 1 & 1 & 1 & 1 & 1 & 1 & 1 & 2 & 2 & 2 & 2 & 2 & 1 & 1 \\
\hline DK & 2 & 2 & 2 & 2 & 3 & 4 & 6 & 6 & 6 & 6 & 6 & 7 & 8 & 2 \\
\hline IE & 3 & 3 & 3 & 11 & 18 & 18 & 19 & 18 & 15 & 12 & 8 & 8 & 6 & 11 \\
\hline LU & 4 & 4 & 6 & 10 & 2 & 2 & 2 & 1 & 1 & 1 & 1 & 1 & 2 & 4 \\
\hline UK & 5 & 6 & 8 & 8 & 8 & 9 & 8 & 8 & 7 & 7 & 7 & 6 & 7 & 6 \\
\hline AT & 6 & 7 & 7 & 4 & 4 & 3 & 3 & 3 & 3 & 3 & 3 & 3 & 3 & 3 \\
\hline CY & 7 & 5 & 4 & 3 & 5 & 6 & 9 & 13 & 19 & 22 & 21 & 22 & 22 & 10 \\
\hline SE & 8 & 8 & 5 & 5 & 6 & 5 & 4 & 5 & 5 & 5 & 4 & 4 & 4 & 5 \\
\hline SI & 9 & 10 & 9 & 6 & 9 & 10 & 12 & 12 & 16 & 17 & 17 & 16 & 12 & 9 \\
\hline $\mathrm{FI}$ & 10 & 9 & 10 & 7 & 7 & 8 & 7 & 7 & 8 & 8 & 11 & 12 & 14 & 7 \\
\hline PT & 11 & 12 & 19 & 17 & 13 & 15 & 15 & 21 & 22 & 20 & 20 & 20 & 18 & 17 \\
\hline FR & 12 & 17 & 17 & 13 & 12 & 12 & 11 & 10 & 10 & 14 & 16 & 19 & 20 & 13 \\
\hline $\mathrm{BE}$ & 13 & 16 & 16 & 14 & 11 & 11 & 10 & 9 & 9 & 10 & 14 & 14 & 19 & 12 \\
\hline ES & 14 & 14 & 15 & 26 & 27 & 28 & 27 & 27 & 27 & 27 & 26 & 26 & 26 & 26 \\
\hline EE & 15 & 11 & 11 & 9 & 23 & 21 & 16 & 15 & 12 & 11 & 10 & 13 & 11 & 15 \\
\hline $\mathrm{CZ}$ & 16 & 18 & 14 & 12 & 15 & 14 & 14 & 14 & 13 & 13 & 13 & 10 & 10 & 14 \\
\hline LT & 17 & 13 & 12 & 15 & 24 & 26 & 20 & 16 & 14 & 15 & 12 & 11 & 13 & 18 \\
\hline $\mathrm{DE}$ & 18 & 19 & 18 & 16 & 10 & 7 & 5 & 4 & 4 & 4 & 5 & 5 & 5 & 8 \\
\hline LV & 19 & 15 & 13 & 19 & 28 & 27 & 21 & 19 & 17 & 16 & 15 & 15 & 15 & 19 \\
\hline MT & 20 & 20 & 20 & 18 & 14 & 13 & 13 & 11 & 11 & 9 & 9 & 9 & 9 & 16 \\
\hline $\mathrm{EL}$ & 21 & 21 & 25 & 25 & 20 & 22 & 28 & 28 & 28 & 28 & 28 & 28 & 28 & 28 \\
\hline HU & 22 & 22 & 24 & 28 & 26 & 25 & 23 & 23 & 21 & 19 & 19 & 18 & 17 & 22 \\
\hline RO & 23 & 23 & 22 & 23 & 21 & 17 & 18 & 20 & 20 & 21 & 22 & 23 & 21 & 20 \\
\hline IT & 24 & 24 & 27 & 27 & 25 & 24 & 24 & 25 & 25 & 26 & 27 & 27 & 27 & 27 \\
\hline HR & 25 & 26 & 23 & 22 & 17 & 19 & 26 & 26 & 26 & 25 & 25 & 25 & 25 & 25 \\
\hline$B G$ & 26 & 25 & 21 & 20 & 19 & 20 & 25 & 24 & 24 & 24 & 24 & 24 & 24 & 23 \\
\hline SK & 27 & 27 & 28 & 24 & 22 & 23 & 22 & 22 & 23 & 23 & 23 & 21 & 23 & 24 \\
\hline PL & 28 & 28 & 26 & 21 & 16 & 16 & 17 & 17 & 18 & 18 & 18 & 17 & 16 & 21 \\
\hline
\end{tabular}

Source: Own elaboration on ground EUROSTAT data (prc_ppp_ind, Ifsa_ergan, Ifsa_urgan, edat_lfse_20).

Results of TOPSIS method and Hellwig's ordering are generally convergent. The results obtained in both methods for the countries of the European Union in the years 2005-2017 indicate that the group of the best-rated countries is more numerous after applying the Hellwig's method than the TOPSIS method. Therefore, Hellwig's method does not indicate such radical differences between countries as the TOPSIS method. After applying the Hellwig's method, Austria was also in the best class, and after calculating the $G T M D_{i}$ (Eq. 10), the changes in the Austrian labour market conditions in the years 2005-2017 were ranked in 3rd place.

In Hellwig's method of ordering in 2005, in the group with the lowest level of assessment of the situation on the labour market, there were Croatia, Bulgaria, Slovakia and Poland. Of these countries, only in Poland, the level of the analysed phenomenon has significantly improved and in 2016 and 2017 the situation on the Polish labour market was allocated into the second class.

Comparing values of Hellwig's synthetic ordering measure and integrated evaluation index in TOPSIS calculated for countries which participate in European Union since 2004, it should be marked that situation on labour markets in those countries is evaluated better from year to year. As it has already been mentioned, Poland, which belongs to these countries, in 2005-2017 obtained the best improvement in positioning of labour market conditions (in both methods). Similar way of improvement can be indicated for Malta and the Czech Republic (Fig. 5 as example for TOPSIS). In both orderings, the assessments of situation on labour market in Cyprus and Slovenia 
deteriorated in 2017 compared to 2005. Both methods indicate that Cyprus in 2005-2010 was highly valued due to the situation on the labour market. However, since 2013, the situation has steadily deteriorated, and consequently this country was positioned in the last places of the third class. In Lithuania, Latvia and Estonia, a sudden, significant deterioration of the labour market conditions was observed in 2009 and 2010. In the subsequent years, the situation started to improve and Estonia and Latvia dealt best with a short crisis (Fig. 5 as example for TOPSIS).

Figure 5: Results of TOPSIS for countries participating in EU since 2004

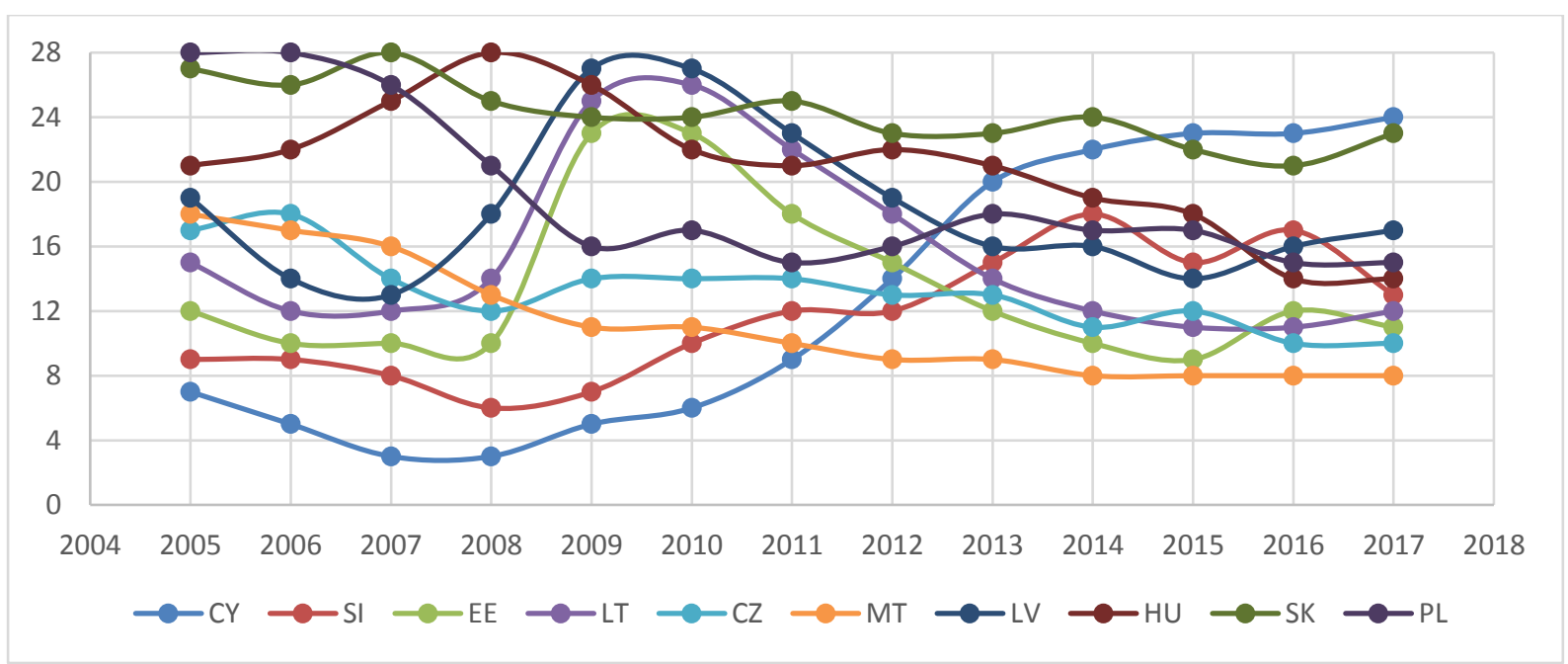

Source: Own elaboration on ground EUROSTAT data (prc_ppp_ind, Ifsa_ergan, Ifsa_urgan, edat_Ifse_20).

On the ground integrated evaluation indices in TOPSIS and Hellwig's ordering synthetic measure, the global taxonomic measure of development was calculated (last columns in Tables 1 and 2). The largest difference in the obtained the $G T M D_{i}$ is visible for Malta (the position in TOPSIS is five places higher than in the Hellwig's method) and Ireland (the position in Hellwig's method is three places higher than in the TOPSIS).

The analysis of the perception of work values was carried out for the Generation Y based on ESS data from 2006, 2010, and 2012. In this study, it was hypothesised that there are differences in the perception of working conditions between people belonging to the young generation in the countries that acceded the European Union in 2004 together with Poland. This problem is well-based due to cultural differences between the analysed countries and the fact that perception of work is an individual and subjective phenomenon, not controlled by meeting conditions necessary for admission to the European Union. The study included four variables related to the characteristics of the younger generation of adults, i.e.: how satisfied with job they are (sat_job), satisfied with balance between time on job and time on other aspects (sat_balance), allowed to decide how daily work is organised (decide_work), allowed to influence policy decisions about activities of organisation (influence_decisions). Generation Y perceives work differently than older generations. Young people, if they are not satisfied with their job, they simply change it, and the balance between private life and work is their important postulate. The attitudes of Generation Y, described in the literature, indicate that they want to decide independently about the style of work and want to have an impact on organizational decisions made in the company. In the study, three other variables were also taken into account: how strong is your satisfaction with life as a whole (sat_life), gender, age (20-34), and country as a variable complementing the characteristics of the distinguished 
groups. In all analysed years, age and gender turned out to be insignificant for the determination of groups. Their importance did not exceed $1 \%$. Therefore, these variables were not included in the further analysis. In 2006 from all the countries that joined the EU in 2004, only Cyprus, Estonia, Hungary, Poland, Slovenia, Slovakia participated in the study. In 2010 and 2012, the Czech Republic and Lithuania joined this group. To determine the number of cluster, the auto-cluster was applied. In the first step of this procedure, BIC was calculated for each number of clusters. In the second step, the greatest change in distance between two closest clusters was found as in hierarchical clustering procedure.

Figure 6 shows the result of the two-stage classification carried out for the year 2006. In the first group are respondents who declared a complete control over the organization of their daily work. They had no influence on policy decisions about activities of organisation. However, they were extremely satisfied with job and with balance between work and their activities, and almost satisfied with life as a whole. This group was mostly observed in Cyprus.

In the second group (Fig. 6) are respondents, who: had in 2006 mid control over daily work organisation, they had influence or had no influence on policy decisions in job, but they were almost satisfied with job and life as a whole. They were neither satisfied nor dissatisfied with work-life balance. This group was mostly observed in Slovenia.

The third group (Fig 6) described respondents, who had no influence on their daily work as well as policy decisions about activities of organisation. However, they are satisfied with job and life, and not satisfied or dissatisfied with balance between life and work. This group was representative for young Poles.

The last group (Fig. 6), mainly observed in Slovakia, include people who almost did not have influence on policy decisions about activities of organisation, had influence or had no influence on daily work. However, they were very satisfied with job and life as whole. They were neither satisfied nor dissatisfied with work-life balance.

Figure 7 shows the result of a two-stage classification carried out for data from 2010. In the first group are respondents who completely had no control over daily work and policy decisions about activities of organisation. However, they were satisfied with job, balance between work and their activities, and with life as a whole. This group was mostly observed in Hungary.

In the second class (Fig. 7) is a group of people who were least determined how to assess selected factors, and they completely had no influence on policy decisions in job. This group was mostly observed in Czech Republic.

The third group (Fig. 7) is mostly characteristic for young Poles, described respondents who had no influence on policy decisions about activities of organisation. However, they were satisfied with job and life, balance between life and work and life as whole. They had or had no influence on workday organisation.

The last group (Fig. 7), mainly observed in Cyprus, include people who assessed all chosen factors in very positive way. 
Figure 6: Results of the twostep cluster analysis (2006)

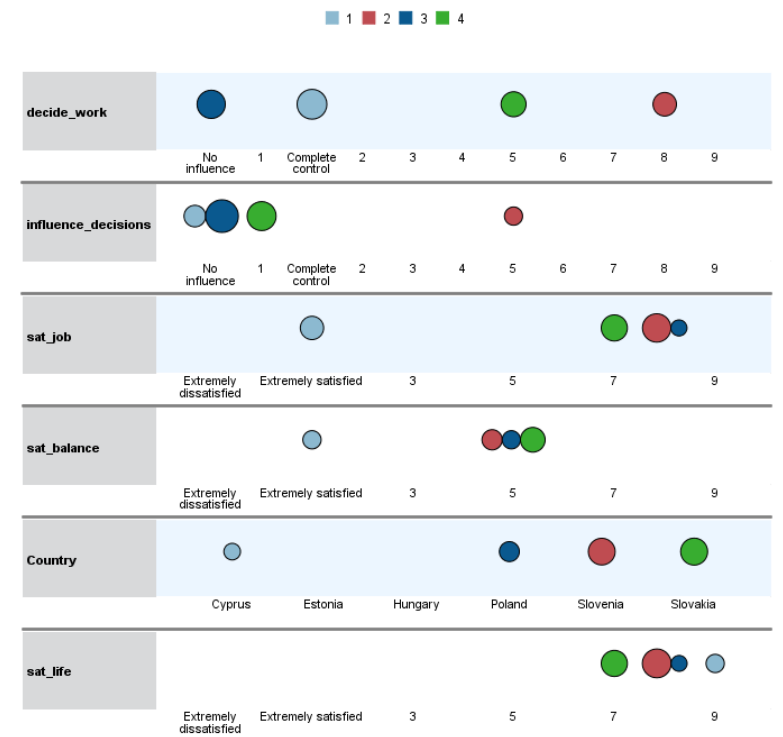

Source: Own elaboration on ESS data (ESS Round 3, 2006).

Figure 8: Results of the twostep cluster analysis (2012)
Figure 7: Results of the twostep cluster analysis (2010)

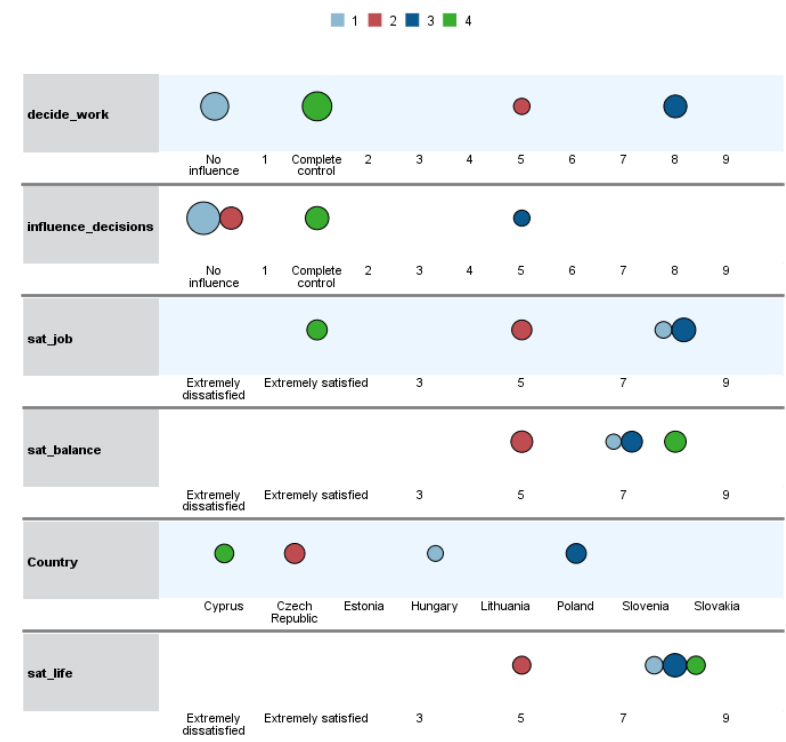

Source: Own elaboration on ESS data (ESS Round 5, 2010).

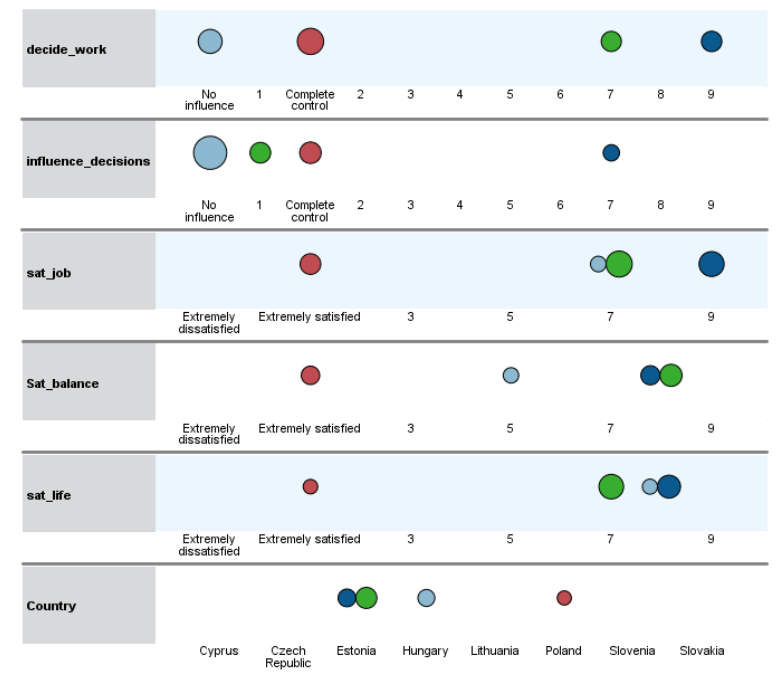

Source: Own elaboration on ESS data (ESS Round 6, 2012).

Figure 8 presents the result of a two-stage classification carried out for 2012. In the first group are respondents who completely had no control over daily work and policy decisions about activities of organisation. However, they were very satisfied with job and with life as a whole. They were neither satisfied nor dissatisfied with balance between work and life. This group was mostly observed in Hungary (see also groups no. 4 in 2006 and first in 2010).

The second group (Fig. 8), mainly observed in Poland, include people who in a very positive way assessed all chosen factors. This group was also characteristic for Cyprus (as in both previous years). In the third group were respondents mainly from Estonia, whose assessments of all factors were very high. The last group differs from the third only in assessment of influence on decisions 
about activities of organisation, which was very low. These groups included mainly Estonians, but also Hungarians, Lithuanians and Slovakians.

\section{Conclusions}

Checking the accuracy of research hypotheses was possible due to the use of the indicated methods of analysis.

Comparing GDP per capita and the employment rate (20-64 and 20-34 age range), it can be noticed that the employment rate increased along with the GDP growth. The exception was Italy, where GDP per capita exceeded the average value calculated for the analysed countries, but the employment rate in both age cohorts was lower than average and lower than in other countries with a similar GDP per capita value (in both years 2005 and 2017). In 2017, the employment rate of 2034 year-olds was the lowest in Italy.

In most countries in 2005, the employment rate of 20-39 year olds was higher than 20-64 year olds (11 countries). In 2017 only in Malta, the United Kingdom, the Netherlands, Ireland and Austria the employment rate of 20-39 year-olds was higher than in the population of 20-64 year-olds. In 2017, there were more countries than in 2005 in which the employment rate of 20-64 year olds exceeded $70 \%$. For 20-39 year-olds, only half of the countries had the employment rate higher than $70 \%$ (similarly as in 2005).

The Hellwig's and TOPSIS methods used in ordering of European countries clearly indicated the changing standards on these labour markets.

The Hellwig's method is a good way to order countries due to selected sets of variables describing the situation on the labour market in comparing to ideal solution. Ordering according to the TOPSIS method involves the comparison of countries with an ideal and non-ideal solution. Both of the applied methods clearly indicated that there are differences in ordering depending on the factor to which we refer when organizing objects in rank order. Combination of the Hellwig's ordering synthetic measure or TOPSIS integrated evaluation index with the classification of annual results received detailed information about changes in the labour market in $28 \mathrm{EU}$ countries. Information on trends in changes on the labour markets was obtained. It was possible to indicate countries where the situation was:

- stable at a very high level: Luxemburg, the Netherlands, Austria;

- stable at a high level: Great Britain, Denmark, Slovenia, Finland, Sweden;

- changing for the better: Poland, Malta, the Czech Republic, Estonia;

- stable at a very low level: Greece, Italy, Croatia;

- constantly fluctuating: Germany, Cyprus, and Hungary.

By usingthe Hellwig's and TOPSIS methods, it was possible to observe changes on labour markets situations in the countries that joined European Union together with Poland, against the background of the remaining countries, reporting the accession earlier or later.

The analysis of work perception made only for the Generation Y using the twostep cluster method indicated that choosing a narrow age cohort there are no differences between 20-39 year-olds from different countries. Gender was also not a significant factor diversifying the perception of quality of life and work. In the literature life and work balance is very often indicated as characteristic of the 
young generation of adults. As the result of conducted analysis it should be pointed that this factor was important in classifying respondents only in $34 \%$ in 2006 , but in the next years, its importance was higher than $50 \%$. Twostep cluster analysis showed the differences between young people from selected countries, thus confirming that the assessments of subjective factors were influenced not by political decisions about the similarity of economic development, but cultural and social factors. Young Poles in 2006 were a group of people dissatisfied with participation in the life of the enterprise in which they were employed. In the following years, their assessments of work values in association to life satisfaction were getting higher. The most satisfied with all assessed aspects of work and balance between life and work were Cypriots.

Summing up, it should be stated that both types of analysis clearly indicated the changing standards on the labour market in the analysed countries and enabled a multi-aspect analysis of a very important social and economic problems.

\section{Acknowledgment}

The project financed under the program of the Minister of Science and Higher Education under the name "Regional Initiative of Excellence" in 2019 - 2022 project number 015/RID/2018/19 the amount of funding PLN 10721040.00.

\section{트 interekon}

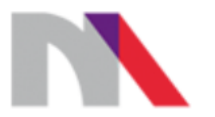

\section{Ministerstwo Nauki i Szkolnictwa Wyższego}

\section{$6 \quad$ References}

Balicki, A. (2013) Statystyczna analiza wielowymiarowa i jej zastosowania społeczno-ekonomiczne. Gdańsk: Wydawnictwo Uniwerystetu Gdańskiego.

Barwińska-Małajowicz, A. (2011) 'Y Generation on the contemporary labour market - dark fiction or completely new quality?', Nierówności społeczne a wzrost gospodarczy, zeszyt 19/2011, pp. 301309.

Bąkowska, J. (2013) 'Managing Generation Y Employees in an International Company', Working Papers in Management, Finance and Economics, Poznań: MBA Poznań-Atlanta.

Crespo, N., Simoes, N. and Pinto, J.C. (2017) "Determinant factors of job quality in Europe', Argumenta Oeconomica, 1(38)2017, pp. 15-40. https://doi.org/10.15611/aoe.2017.1.01

Deal, J.J. (2007) Retiring the Generation Gap: How Employees Young and Old Can Find Common Ground, San Francisco: John Wiley \& Son.

ESS Round 3: European Social Survey Round 3 Data (2006). Data file edition 3.6. NSD - Norwegian Centre for Research Data, Norway - Data Archive and distributor of ESS data for ESS ERIC.

ESS Round 5: European Social Survey Round 5 Data (2010). Data file edition 3.3. NSD - Norwegian Centre for Research Data, Norway - Data Archive and distributor of ESS data for ESS ERIC.

ESS Round 6: European Social Survey Round 6 Data (2012). Data file edition 2.3. NSD - Norwegian Centre for Research Data, Norway - Data Archive and distributor of ESS data for ESS ERIC. 
Favero, L. W. and Heath, R. G. (2012) 'Generational Perspectives in the Workplace. Interpreting the Discourses That Constitute Women's Struggle to Balance Work and Life', International Journal of Business Communication, 49(4), pp. 332 - 356. DOI: 10.1177/0021943612456037.

Gentry, W. A., Deal, J.J., Griggs, T.L., Mondore, S.P. and Cox, B.D. (2011) 'A comparison of generational differences in endorsement of leadership practices with actual leadership skill level', Consulting Psychology Journal: Practice \& Research, 63(1), pp. 39-49. https://doi.org/10.1037/a0023015

Gursoy, D., Maier, T.A. and Chi, C.G. (2008) 'Generational differences: An examination of work values and generational gaps in the hospitality workforce', International Journal of Hospitality Management, 27 (2008), pp. 448-458. https://doi.org/10.1016/j.ijhm.2007.11.002

Hansen, J-I. and Leuty, M.E. (2012) 'Work values across generations', Journal of Career Assessment, 20(1), pp. 34-52. DOI: 10.1177/1069072711417163.

https://ec.europa.eu/eurostat.

Hellwig, Z. (1968) 'Zastosowanie metody taksonomicznej do typologicznego podziału krajów ze względu na poziom ich rozwoju oraz zasoby i strukturę wykwalifikowanych kadr', Przegląd statystyczny, No.4, pp. 307-327.

Hole, D., Zhang, L. and Schwartz, J. (2010) 'Talking About Whose Generation? Why Western generational models can't account for a global workforce', Deloitte Review, Issue 6, pp. 83-97.

Hwang, C.L. and Yoon, K. (1981) Multiple attribute decision-making: Methods and applications. Berlin: Springer. https://doi.org/10.1007/978-3-642-48318-9

ILO, International Labour Organization. (1944) Declaration of Philadelphia. Available at: https://www.ilo.org/legacy/english/inwork/cb-policy-guide/declarationofPhiladelphia1944.pdf (Accessed 28 June 2019).

Kasnauskiene G. and Michnevic K. (2017) 'Contribution of increased life expectancy to economic growth: evidence from CEE countries', International Journal of Economic Sciences, Vol. VI(2), pp. 82-99., 10.20472/ES.2017.6.2.005.

Khera S.N. and Malik S. (2014) 'Life priorities and Work Preferences of Generation Y: an exploratory analysis in Indian Context', Jindal Jorurnal of Business Research, 3(1\&2), pp. 63-76. DOI: $10.1177 / 2278682116643607$.

Kim, H.J, Knight, D.K and Crutsinger, C. (2009) 'Generation Y employees' retail work experience: The mediating effect of job characteristics', Journal of Business Research, 62 (2009), 548-556. Doi:10.1016/j.jbusres.2008.06.014.

Kołodziejczyk W. (2018) 'Criteria Used in the LFS to Identify the Population'S Economic Activity Status Vs. the Respondents' Subjective Views: Implications for Unemployment Research', Econometrics Ekonometria. Advances in Applied Data Analysis, 2018, Vol.22 No.3, pp. 99-113, DOI: 10.15611/eada.2018.3.07.

Martini, C. (2005) 'From high maintenance to high productivity. What managers need to know about Generation Y', Industrial and Commercial Training, Vol. 37, no. 1 2005, pp. 39-44. https://doi.org/10.1108/00197850510699965

Nowak, E. (1990) Metody taksonomiczne w klasyfikacji obiektów społeczno-gospodarczych, Warszawa: PWE. 
Lester, S.W., Standifer, R.L., Schultz, N.J. and Windsor, J.M. (2012) 'Actual Versus Perceived Generational Differences at Work: An Empirical Examination', Journal of Leadrship \& Organizational Studies, 19(3), pp. 341-354. DOI: 10.11.77/1548051812442747.

Lichy, J. (2012) 'Towards an international culture: Gen Y students and SNS?', Active Learning in Higher Education, 13(2), pp. 101-116. DOI: 10.11.77/1469787412441289.

Lyons, S.T., Duxbury, L. and Higgins, C. (2007) 'An empirical assessment of generational differences in basic human values', Psychologica Reports, Vol. 101, pp. 339-352. DOI: 10.2466/PR0.101.2.339-352.

Panek, T. (ed.) (2014) Statystyka społeczna, Warszawa: Polskie Wydawnictwo Ekonomiczne.

Parment, A. (2013) Die Generation Y. Mitarbeiter der Zukunft motivieren, integrieren, führen. $2^{\text {nd }}$ edition, Wiesbaden: Springer Gabler.

Parry, E. and Urwin, P. (2011) 'Generational Differences in Work Values: A Review of Theory and Evidence', International Journal of Management Reviews, Vol. 13, 79-96. DOI: 10.1111/j.14682370.2010.00285.x.

Rogozińska-Pawełczyk, A. (2014) 'Zarządzanie kapitałem ludzkim w różnym wieku jako wyzwanie dla rynku pracy', in: Rogozińska-Pawełczyk, A. (ed.), Pokolenia na rynku pracy, Łódź: Wydawnictwo Uniwersytetu Łódzkiego.

Schiopu, D. (2010) 'Applying TwoStep Cluster Analysis for Identifying Bank Customers' Profile', Buletinul Universităţii Petrol - Gaze din Ploieşti. Seria Ştiinţe Economice, Vol. LXII, No. 3/2010, pp. 66-75.

Schroer, W. (2015) Generations $X, Y, Z$ and the Others, [Online], Available at: http://socialmarketing.org/archives/generations-xy-z-and-the-others/ (Accessed: 30 September 2018).

Smith, D.N., Roebuck, D. and Elhaddaoui, T. (2016) 'Organizational leadership and work-life integration: Insights from three generations of men', Creighton Journal of Interdisciplinary Leadership, 2(1), May 2016, pp. 54-70. DOI: http://dx.doi.org/10.17062/CJIL.v2i1.31.

Smola, K.W. and Sutton, C.D. (2002) 'Generational Differences: Revisiting Generational Work Values for the New Millennium', Journal of Organizational Behavior, Vol. 23, No. 4, Special Issue: Brave New Workplace: Organizational Behavior in the Electronic Age (Jun., 2002), pp. 363-382. DOI: 10.1002/job.147.

Stanimir, A. (2015a) 'Generation Y - Characteristics of Attitudes on Labour Market', Mediterranean Journal of Social Sciences, 6(2S5), pp. 22-28. DOI:10.5901/mjss.2015.v6n2s5p22.

Stanimir, A. (2015b) 'Most important and useful skills in the labour market - Generation Y point of view', in: Rotschedl J., Cermakova K. (eds.), Proceedings of 16th International Academic Conference, Amsterdam, pp. 493-499, DOI: 10.20472/IAC.2015.016.066.

Stanimir A. (2014) 'Participation in the labour market - Generation $Y$ and other age groups', Academic Journal of Interdisciplinary Studies, MCSER Publishing, Rome-Italy, vol. 3 no.3., pp. 111-116, DOI: 10.5901/ajis.2014.v3n3p111.

Szwedzik, A. (2015) 'Bezrobocie przyczyną problemów człowieka i jego rodziny', in: Pikuła, N.G. (ed.), Marginalizacja na rynku pracy. Teorie a implikacje praktyczne. Kraków, Oficyna Wydawnicza Impuls.

Tolbize, A. (2008) Generational differences in the workplace, [Online], Available at: http://rtc.umn.edu/docs/2_18_Gen_diff_workplace.pdf (Accessed: 10 February 2015).

Treuren, G. and Anderson, K. (2010) 'The employment expectations of different age cohorts: is generation $Y$ really that different?', Australian Journal of Career Development, 19(20), Winter, pp. 49-60. DOI: $10.1177 / 103841621001900207$. 
Trpkova, M. and Tevdovski, D. (2010) 'Twostep cluster analysis: Segmentation of largest companies in Macedonia', in Kovács, P., Szép, K. and Katona, T. (eds.), Proceedings of the Challenges for Analysis of the Economy, the Businesses, and Social Progress International Scientific Conference, Szeged.

Wyland, R., Lester, S. W., Ehrhardt, K., and Standifer, R. (2016) 'An examination of the relationship between the work-school interface, job satisfaction, and job performance', Journal of Business and Psychology, 31(2), 187-203. https://doi.org/10.1007/s10869-015-9415-8 